\title{
Pengaruh Model Pembelajaran Think Pair Share Terhadap Kemampuan Berpikir Kritis Siswa pada Mata Kuliah Demokrasi Pancasila
}

\author{
Ahmad Fauzan 1, Rispawati', M. Salam ${ }^{3}$ \\ 1,2Prodi Pendidikan Pancasila dan Kewarganegaraan, Fakultas Keguruan dan Ilmu Pendidikan, \\ Universitas Mataram, Indonesia \\ ${ }^{3}$ Prodi Pendidikan Pancasila dan Kewarganegaraan, Fakultas Keguruan dan Ilmu Pendidikan, \\ Universitas Jambi, Indonesia \\ 1ahmadfauzan18@unram.ac.id
}

\begin{abstract}
This research is conducted in the Democracy of Pancasila Course at Pancasila and Civic Education (PPKn) Department of the University of Jambi. Students have difficulties in both answering critically when the lecturer asks questions and criticizing questions from their peers when responding to group discussion questions. This is due to the weak thinking strategies used in the classroom so that the students' ability does not meet the expectations of critical thinking. One of the efforts made to overcome this problem is to apply the Think Pair Share (TPS) learning model. This study aims to determine the influence of the Think Pair Share learning model on students' critical thinking ability. This research was PreExperimental Design using the Intact Group Comparison design. The population in this study was all students of the PPKn Department in University of Jambi. The sample in this study were students from class $A$ and class $B$. Class $B$ was used as an experimental class where students were taught using the Think Pair Share learning model. Meanwhile, class $A$ was the control class where students learned using conventional learning models. The instrument used in this study was a test instrument. The data collected were analyzed using the T test. Based on the results of the research, it is concluded that critical thinking ability of students who were taught using the Think Pair Share model in the Democracy of Pancasila Course were higher than students who were taught using conventional learning models.
\end{abstract}

Keywords: Think Pair Share (TPS), critical thinking, Democracy of Pancasila Course

\section{ABSTRAK}

Penelitian ini berdasarkan hasil pengamatan pada Mata Kuliah Demokrasi Pancasila di Program Studi Pendidikan Pancasila dan Kewarganegaraan (PPKn) Universitas Jambi. Mahasiswa banyak mengalami kesulitan memberikan jawaban secara kritis ketika dosen bertanya, kemudian pada saat menanggapi pertanyaan-pertanyaan diskusi kelompok, mereka juga sulit untuk mengkritisi pertanyaan dari teman-temannya. Hal ini disebabkan lemahnya strategi berpikir yang digunakan dalam kelas sehingga kemampuan berpikir secara kritis belum sesuai dengan harapan. Upaya yang dapat dilakukan untuk mengatasi persoalan tersebut adalah penerapan model pembelajaran Think Pair Share (TPS). Tujuan dilakukannya penelitian ini adalah untuk mengetahui seberapa besar pengaruh model pembelajaran TPS terhadap kemampuan berpikir kritis mahasiswa. Adapun jenis penelitian yang digunakan adalah Pre-Exsperimental Design dengan menggunakan desain Intact Group Comparison. Populasi pada penelitian ini adalah seluruh mahasiswa program studi PPKn Universitas Jambi. Sedangkan yang menjadi sampel pada penelitian ini adalah mahasiswa kelas A dan kelas B. Mahasiswa kelas B digunakan sebagai kelas eksperimen yang diajarkan 
dengan model pembelajaran Think Pair Share, sedangkan mahasiswa kelas A sebagai kelas kontrol yang belajar dengan menggunakan model pembelajaran konvensional. Intrumen yang digunakan dalam penelitian ini adalah instrumen tes. Data yang terkumpul dianalisis dengan mengguanakan uji T. Berdasarkan hasil penelitian, disimpulkan bahwa kemampuan berpikir kritis mahasiswa yang diajarkan dengan menggunakan model pembelajaran Think Pair Share pada mata kuliah Demokrasi Pancasila menjadi lebih tinggi dibandingkan dengan mahasiswa yang diajarkan dengan menggunakan model pembelajaran konvensional.

Kata Kunci: Think Pair Share (TPS), berpikir kritis, mata kuliah Demokrasi Pancasila

This work is licensed under the Creative Commons Attribution-ShareAlike 4.0 International License. (02021 by the author(s).

Received: August 72020

Revised: March 92021

Accepted: March 112021

\section{PENDAHULUAN}

Pendidikan merupakan wadah bagi masyarakat untuk dapat meningkatkan potensi diri bagi setiap individu, kepribadian baik, memiliki soft skill yang memadai, serta menjadi bangsa yang cerdas dan bermartabat. Pendidikan diharapkan mampu membawa perubahan yang sangat signifikan demi kemajuan bangsa ini. Berdasarkan Undang-Undang No. 20 tahun 2003, sistem pendidikan nasional berfungsi meningkatkan kemampuan peserta didik dengan membentuk watak serta peradaban yang bermartabat dalam rangka mencerdaskan kehidupan anak negeri yang bertaqwa terhadap Tuhan Yang Maha Esa, berahklakulkarimah, inovatif, kreatif, mandiri, sehat, serta menjadi warga negara yang bertanggung jawab (Kemendikbud, 2003).

Berdasarkan pengamatan peneliti di lapangan, mahasiswa Program Studi Pendidikan Pancasila dan Kewarganegaraan (PPKn) Fakultas Keguruan dan Ilmu Pendidikan (FKIP) Universitas Jambi masih ada yang kesulitan dalam memahami konteks materi yang diberikan oleh dosen di kelas, terutama dalam berpikir kritis. Hal ini dibuktikan ketika dosen memberikan permasalahan/kasus yang berkaitan dengan materi kuliah, mereka sulit untuk memberikan jawaban mereka secara kritis, kemudian pada saat menanggapi pertanyaan-pertanyaan diskusi kelompok, mereka juga sulit untuk mengkritisi pertanyaan dari teman mereka. Hal ini disebabkan lemahnya strategi dalam berpikir yang digunakan dalam kelas sehingga kemampuan berpikir mahasiswa belum sesuai dengan harapan. Berpikir kritis merupakan sebuah proses sistem kognitif untuk menganalisis suatu pengetahuan yang sedang dipikirkan sehingga dapat menyelasaikan masalah dengan tepat dan cepat (Cahyono, 2017).

Berpikir kritis yang dikemukakan oleh Glaser (Fisher, 2008) menyatakan bahwa upaya berpikir seseorang dalam menyikapi suatu masalah berada pada jangkauan pengalaman yang dimilikinya. Berpikir kritis ini juga berhubungan dengan metode penalaran logis sehingga dapat meningkatkan keterampilan dalam penerapan metode tersebut. Upaya keras diperlukan dalam tuntutan berpikir kritis untuk memeriksa setiap asumsi atau keyakinan berdasarkan fakta serta kesimpulan lanjutan yang diakibatkannya. Pemikiran secara mendalam atau aktif harus dilakukan untuk berpikir kritis dengan menganalisis dan mencari kebenarankebenaran atau alasan tentang pengetahuan sehingga dapat dipercaya. 
Menurut Lipman (Moore, 2005) terdapat perbedaan antara berpikir biasa dan berpikir kritis, yaitu berpikir biasa merupakan pemikiran sederhana dan tidak memiliki standar dalam menentukan alur berpikir, sedangkan berpikir kritis adalah proses berpikir yang lebih kompleks dan didasarkan pada standar objektivitas dan konsistensi. Dalam proses critical thinking terdapat nilai komplikasi yang tinggi dan juga konsisten, sehingga memiliki kemampuan berpikir yang lebih tinggi dibandingkan berpikir biasa; di dalamnya terdapat proses mengevaluasi, menganalisis, dan menyimpulkan.

Dalam proses perkembangan berpikir kritis, setiap mahasiswa membutuhkan pembiasaan untuk mencapai tahap tersebut. Selain itu, faktor antusiasme mahasiswa pada setiap kegiatan proses pembelajaran juga berpengaruh terhadap proses tersebut, seperti mengamati, merumuskan masalah, hingga sampai ke tahapan menganalisis. Proses tersebut harus menjadi dorongan dalam meningkatkan motivasi belajar mereka (Yunita et al., 2019).

Pembelajaran dengan menggunakan pendekatan berpikir kritis pada bidang studi lainya bertujuan untuk meningkatkan keterampilan berpikir mahasiswa dan menyiapkan para mahasiswa agar mampu menghadapi era globalisasi. Selanjutnya, agar berpikir kritis ini dapat dikembangkan oleh mahasiswa, maka diperlukan salah satu metode yang mampu meningkatkan berpikir kritis mahasiswa terhadap pembelajaran di kelas, di antaranya dengan metode Cooperative Learning tipe Think Pair Share.

Menurut Cahyono (2016), indikator kemampuan berpikir kritis bagi siswa terdiri dari validitas pertanyaan, pemberian pejelasan, informasi yang diberikan baik dan benar, kredibilitas sumber yang jelas, memperhatikan seluruh kondisi dan situasi, mengutamakan relevansi, mementingkan hal yang asli, mendasar dan solutif, berpikir lebih luas dan terbuka serta mengambil sikap yang baik, menelaah sesuatu berdasarkan bukti yang cukup jelas, memberikan penjelasan yang luas sehingga masalah yang dihadapi dapat diselesaikan secara sistematis dan teratur.

Frank Lyman merupakan salah seorang yang mengembangkan pembelajaran kooperatif Think Pair Share dari Universitas Maryland pada tahun 1985 (Trianto, 2007). Think Pair Share merupakan jenis cooperative learning yang dibuat untuk mempengaruhi pola interaksi siswa. Adapun pelaksanaan implementasi model pembelajaran TPS yang dikemukakan oleh Arends terdiri atas tiga Langkah, yakni: berpikir (thinking) di mana guru memberikan pertanyaan atau masalah yang berkaitan dengan pembelajaran. Siswa diberikan waktu beberapa menit untuk berpikir mandiri dalam menjawab pertanyaan yang telah diberikan (Trianto, 2011). Langkah kedua yaitu memasangkan (pairing) di mana guru menginstruksikan kepada siswa agar dapat mencari pasangannya serta melakukan diskusi sesuai dengan bahan diskusi yang telah mereka dapatkan dari guru tersebut. Selanjutnya langkah yang ketiga yakni berbagi (sharing), di mana guru meminta kepada masingmasing kelompok berpasangan untuk memberikan penjelasan terhadap materi yang telah didiskusikan kepada seluruh teman-teman kelas.

Berdasarkan permasalahan di atas, maka peneliti ingin menjawab pertanyaan: (1) Apakah model pembelajaran Think Pair Share dapat meningkatkan kemampuan critical thinking mahasiswa pada mata kuliah Demokrasi Pancasila? (2) 
Apakah model pembelajaran konvensional dapat meningkatkan kemampuan critical thinking mahasiswa pada mata kuliah Demokrasi Pancasila? Adapun tujuan dalam penelitian ini adalah untuk melihat seberapa besar signifikansi model pembelajaran think pair share dibandingkan dengan model pembelajaran konvensional terhadap kemampuan critical thinking mahasiswa pada mata kuliah Demokrasi Pancasila.

\section{METODE PENELITIAN}

Jenis penelitian ini adalah pre-exsperimental design. Metode penelitian yang digunakan adalah metode rancangan intact group comparison yang bertujuan untuk mengevaluasi pengaruh suatu perlakuan/tindakan/treatment pendidikan terhadap tingkah laku mahasiswa atau menguji hipotesis tentang ada atau tidaknya pengaruh tindakan itu bila dibandingkan dengan tindakan lain (Sugiyono, 2014).

Objek dalam penelitian ini adalah kemampuan critical thinking mahasiswa pada mata kuliah Demokrasi Pancasila dengan menggunakan model pembelajaran kooperatif (cooperative learning) tipe think pair share. Subjek dalam penelitian ini adalah mahasiswa program studi PPKn semester 4, yaitu kelas A dan kelas B angkatan tahun 2014/2015 Universitas Jambi. Kelas A digunakan sebagai kelompok kontrol dengan menggunakan model pembelajaran konvensional. Sedangkan sebagai kelompok eksperimen kelas B menggunakan model pembelajaran think pair share.

\section{HASIL DAN PEMBAHASAN}

Setelah tes dilakukan maka data tentang kemampuan berpikir kritis mahasiswa dengan menggunakan model pembelajaran think pair share dan model konvensional dapat dilihat pada tabel dibawah ini:

Tabel 1. Implementasi Pembelajaran Model Think Pair Share

\begin{tabular}{|c|c|c|c|c|c|c|c|}
\hline & $\mathbf{N}$ & Min & Max & & ean & Std. & Variance \\
\hline & Statistic & Statistic & Statistic & Statistic & Std. Error & Statistic & Statistic \\
\hline Eksperimen & 26 & 60 & 95 & 77.42 & 1.924 & 9.811 & 96.254 \\
\hline Kontrol & 25 & 55 & 90 & 72.60 & 1.661 & 8.307 & 69.000 \\
\hline $\begin{array}{l}\text { Valid N } \\
\text { (listwise) }\end{array}$ & 25 & & & & & & \\
\hline
\end{tabular}

Tabel di atas mengemukakan bahwa pada implementasi model pembelajaran Think Pair Share pada mata kuliah Demokrasi Pancasila pada prodi PPKn tahun angktatan 2014 kelas eksperimen diperoleh skor kemampuan berpikir kritis mahasiswa rata-rata77,42, sedangkan skor kemampuan berpikir kritis mahasiswa kelas kontrol yaitu rata-rata 72,60.

\section{Analisis Data}

Analisis data pada penelitian ini menggunakan uji hipotesis di mana 
16 | Ahmad Fauzan, et.al.

Pengaruh Model Pembelajaran...

sebelumnya dilakukan uji prasyarat sebagai berikut.

\section{Uji Prasyarat}

Uji prasyarat ini dilakukan melalui dua pengujian yaitu normalitas dan homogenitas. Dari hasil pengujian normalitas menggunakan program SPSS, didapatkan sig. pada kelas eksperimen adalah 0,089, sedangkan kelas kontrol adalah 0,173. Dari hasil pengujian ini dapat kita simpulkan bahwa kelas kontrol memiliki probabilitas lebih besar dari 0,05 atau hasil data kemampuan berpikir kritisnya berdistribusi normal. Kemudian kita lihat kelas eksperimen memiliki probalitas yang lebih besar dari 0,05 atau hasil data berpikir kritisnya berdistribusi normal.

Selanjutnya untuk melihat uji homogenitas penelitian melalui data kemampuan berpikir kritis siswa (gain score), dilakukan hasil uji data dengan menggunakan SPSS, dan hasilnya adalah 0,385. Dapat disimpulkan bahwa kelas kontrol dan kelas eksperimen memiliki probalitas lebih besar dari 0,005 atau data kemampuan berpikir kritis kelas kontrol dan eskperimen memiliki varian yang sama atau homogen.

\section{Uji Normalitas}

Karena nilai signifikansi kelas eksperimen 0,029<0,05 maka data tidak berdistribusi normal, sehingga uji hpotesis yang digunakan adalah uji non parametrik Mean Whitney $u$.

Tabel 2. Uji Normalitas

\begin{tabular}{cllllll}
\hline \multirow{2}{*}{ Model } & \multicolumn{3}{l}{ Kolmogorov-Smirnov a $^{\text {Shapiro-Wilk }}$} \\
\cline { 2 - 7 } & Statistic & Df & Sig. & Statistic & Df & Sig. \\
\hline Nilai Eksperimen & .181 & 26 & .029 & .941 & 26 & .141 \\
Kontrol & .174 & 25 & .050 & .965 & 25 & .519 \\
\hline
\end{tabular}

a. Lilliefors Significance Correction

\section{Uji Hipotesis}

Uji hipotesis dengan non parametrik Mann-Whitney Test (Tabel 3).

Tabel 3. Mann-Whitney Test

Test Statistics ${ }^{a}$

\begin{tabular}{ll}
\hline & Nilai \\
\hline Mann-Whitney U & 225.000 \\
Wilcoxon $\mathrm{W}$ & 550.000 \\
$\mathrm{Z}$ & -1.909 \\
Asymp. Sig. (2-tailed) & \\
a. Grouping Variable: Model & \\
0,056/2=0,028 maka 0,028<0,05 sehinga dapat disimpulkan terdapat perbedaan yang \\
signifikan.
\end{tabular}




\section{Pembahasan}

Bardasarkan analisis data dan sesuai dengan pembahasan serta tujuan penelitian yang dilakukan di program studi Pendidikan Pancasila dan Kewarganegaraan (PPKn), terdapat signifikansi perbedaan antara kemampuan berpikir kritis mahasiswa dengan menggunakan model pembelajaran Think Pair Share dan metode ceramah. Dari hasil perhitungan diperoleh kesimpulan bahwa skor kemampuan berpikir kritis mahasiswa dengan menerapkan model pembelajaran Think Pair Share pada Mata Kuliah Demokrasi Pancasila pada program studi PPKn angkatan 2014 kelas B memiliki rata-rata 77,42. Sementara itu, skor kemampuan berpikir kritis mahasiswa dengan menerapkan model pembelajaran konvensional pada Mata Kuliah Demokrasi Pancasila pada program studi PPKn angkatan 2014 kelas A sebagai kelas kontrol memiliki rata-rata 72,60. Hasil perhitungan uji non parametrik Mann-Whitney Test 0,056/2=0,028, maka 0,028<0,05 sehinga dapat disimpulkan terdapat perbedaan yang signifikan. Artinya terdapat perbedaan kemampuan berpikir kritis mahasiswa kelas B yang menerapkan model pembelajaran Think Pair Share dengan kelas A yang menerapkan metode ceramah.

Hasil perhitungan uji non parametrik Mann-Whitney Test 0,056/2=0,028 maka 0,028<0,05 sehingga ditarik kesimpulan bahwa terdapat perbedaan yang signifikan. Penerapan model pembelajaran Think Pair Share (TPS) terhadap kemampuan berpikir kritis mahasiswa pada mata kuliah Demokrasi Pancasila ditemukan lebih tinggi dibandingkan dengan kelas kontrol yang penerapan pembelajarannya menggunakan metode penjelasan/ceramah. Hal ini disebabkan oleh perlakuan berbeda yang diterapkan pada mahasiswa kelas ekperimen dalam pembelajaran tersebut. Pada tahap thinking kelas eksperimen mahasiswa dilatih berpikir secara mandiri untuk menggali informasi yang telah didapatkannya. Mahasiswa mendapatkan kesempatan memperluas informasi serta memperkaya pengetahuan sesuai dengan materi yang dibahas, serta mampu menganalisis pertanyaan yang telah diberikan oleh dosen.

Dalam tahap pairing, mahasiswa berdiskusi secara berpasangan. Mereka bertukar pendapat tentang pertanyaan yang diajukan, di mana sebelumnya mahasiswa telah mencarinya secara individu. Pada saat diskusi masing-masing mahasiswa yang berpasangan (kelompok kecil), mereka saling memperkuat pemahaman terhadap masalah yang diberikan untuk dianalisis secara bersama sehingga mahasiswa tersebut dapat menemukan benang merah dari apa yang telah mereka diskusikan. Hal ini diperkuat oleh pernyataan Lie bahwa pada model cooperative learning type Think Pair Share siswa diberikan kesempatan belajar mandiri dan berkolaborasi dengan teman tim serta teman lainnya dalam pembelajaran.(Lie, 2005). Selanjutnya pada tahapan sharing mahasiswa diminta untuk memberikan informasi kepada teman-teman lainnya mengenai diskusi yang telah dilakukan dalam kelompok kecil (berpasangan). Tahapan ini dibagi atas dua langkah, pertama, sharing terbatas, setiap pasangan saling memberikan jawaban pada pasangan lainnya secara bergantian dalam kelompok besar sehingga masing-masing mahasiswa tersebut dapat informasi yang lebih luas. Langkah kedua adalah sharing kelas, langkah ini dilakukan dengan presentasi yang ditujukan kepada satu orang pasangan sebagai perwakilan kelompok besar. Setiap pasangan dari masing-masing 
kelompok besar memberikan jawaban kepada teman-teman kelas dan mempertahankan argumentasi dari pasangan kelompok yang tidak presentasi. Selanjutnya mahasiswa yang tidak presentasi diminta untuk berpendapat terhadap jawaban yang telah diberikan oleh kelompok presentasi sehingga informasi yang didapatkan sangat luas.

Pada tahap Pairing, mahasiswa dapat mengoptimalkan diskusi karena anggota setiap kelompok terdiri dari dua orang. Keterlibatan mahasiswa dalam bekerja sama diharapkan dapat berjalan secara efektif. Mahasiswa bertukar argumentasi dengan pasangannya, menyatukan persepsi dalam pembahasan sehingga mahasiswa dapat menyempurnakan dan memperluas jawabannya secara baik. Kerja sama dalam kelompok tersebut diharapkan membantu mahasiswa dalam memahami materi yang telah diberikan oleh dosen.

Keunggulan selanjutnya, dilihat dari tahap sharing yaitu melatih mental (keberanian) mahasiswa dalam mengemukakan pendapat. Kelompok diminta untuk maju membacakan jawaban atas pertanyaan yang telah diberikan oleh dosen, sedangkan kelompok lain memberikan sanggahan, kritikan, atau pertanyaan. Pada tahapan ini mahasiswa dibiasakan untuk mengemukakan pendapat (jawaban) kepada teman-temannya yang lain, sehingga mahasiswa dapat lebih aktif dalam pembelajaran. Masing-masing pasangan kelompok memiliki kesempatan untuk saling berbagi dengan pasangan kelompok lainnya.

Keunggulan-keunggulan yang dimiliki dalam pembelajaran kooperatif Think and Share menunjukan adanya keaktifan mahasiswa dalam pembelajaran di kelas, sehingga melalui cooperative learning tipe Think Pair Share dapat membantu siswa dalam mengeksplorasi dan melatih mental dalam berbagai sikap dan nilai (Arianti, 2011). Melalui kegiatan kelompok siswa dapat menjadi lebih aktif dalam pembelajaran, lebih terbuka dalam berpendapat, mengeluarkan ide dan gagasannya serta menjadi percaya diri dalam menjawab pertanyaan-pertanyaan dari guru.

Model pembelajaran Think Pair Share ini memiliki keunggulan bagi mahasiswa dalam belajar, memberikan mahasiswa pengalaman baru dalam belajar dan mendapatkan suasana belajar yang berbeda dari sebelumnya. Pembelajaran model Think Pair Share ini melatih mahasiswa untuk meningkatkan kemampuan berpikir kritis dalam menjawab beberapa pertanyaan analisis yang diberikan oleh dosen, berupa studi kasus. Dengan studi kasus ini mahasiswa diajarkan untuk menggali informasi, memotivasi untuk berpikir, dan mengembangkan cara berpikir mahasiswa untuk menjawab pertanyan-pertanyaan dari dosen. Buchari (2009) berpendapat bahwa pembelajaran Think Pair Share dapat meningkatkan cara berpikir siswa, memberikan pengetahuan yang luas kepada siswa, meningkatkan partisipasi siswa dalam mengeluarkan pendapat, serta mengasah daya berpikir siswa. Selain itu siswa juga dapat memecahkan permasalahan dari berbagai sudut pandang, dengan tujuan untuk mencapai sebuah pemahaman yang sama dalam memberikan jawaban. Oleh karena itu dengan pembelajaran model Think Pair Share ini guru menjadi lebih produktif dalam merumuskan masalah di awal pelajaran. Penyajian yang sistematis dapat memancing rasa penasaran siswa dan memotivasi siswa untuk memberi solusi dari setiap permasalahan yang diberikan. 
Penelitian model Think Pair Share banyak digunakan oleh peneliti sebelumnya. Penelitian tersebut antara lain, mengenai pengaruh Think Pair Share dengan media gambar terhadap kemampuan berpikir kritis siswa. Penggunaan strategi pembelajaran dengan media gambar dapat meningkatkan kemampuan berpikir kritis siswa (Ndae \& Widyaningrum, 2020). TPS juga dapat dikombinasikan dengan metode eksperimen seperti yang dilakukan terhadap hasil belajar pada mata pelajaran Kimia mahasiswa di Papua (Siregar, 2012). Berdasarkan hasil temuan oleh peneliti-peneliti sebelumnya, penelitian ini sangat relevan karena rata-rata kemampuan crtical thinking mahasiswa dalam kelas eksperimen lebih baik dibandingkan kelas kontrol yang menggunakan pembelajaran konvensional.

Model pembelajaran TPS ini bukan merupakan model pembelajaran yang sempurna, tetapi juga memiliki kelemahan. Beberapa kelemahannya adalah masih terdapatnya kesulitan dalam menerapkannya di sekolah karena rata-rata kemampuan siswanya masih rendah. Waktu yang diberikan juga sangat terbatas, sedangkan kelompok yang dibentuk banyak, sehingga kurang efisien dalam pembelajaran. Hartina (2008) menjelaskan hambatannya di antaranya: 1) siswa yang memiliki kemampuan akdemik tinggi akan merasa kesulitan dalam mengeksplor kemampuannya terhadap siswa yang memiliki kemampuan akademik rendah. Hal ini akan berdampak kepada kerjasama tim/kelompok; 2) terhambatnya siswa mendapatkan pertemuan yang efektif, sehingga apa yang seharusnya dipelajari tidak tercapai oleh siswa; 3) guru hanya terfokus pada penilaian hasil kerja kelompok, seharusnya guru lebih memperhatikan prestasi siswa setiap individu; 4) memberikan kesadaran pada kelompok memerlukan waktu yang cukup panjang, tidak bisa hanya diberikan satu kali dalam setiap penerapan strategi; 5) mengutama-kan kemampuan individu tanpa memperhatikan kemampuan bekerja sama, dengan demikian melalui pembelajaran kooperatif ini siswa diharapkan dapat membangun kepercayaan diri, meskipun bukan suatu hal yang mudah bagi siswa namun dapat menjadi cara bagi siswa untuk lebih konsisten dalam belajar (Rosita \& Leonard, 2015).

Uraian di atas menunjukkan bahwa setiap model pembelajaran yang dirancang oleh pengajar, baik guru atau dosen tidak sepenuhnya sempurna, namun dengan demikian setidaknya tenaga pengajar sudah berinisiatif untuk melakukan perubahan dalam setiap pembelajaran yang akan diberikan kepada setiap anak didiknya.

Untuk meningkatkan motivasi dan minat belajar siswa, perlu diberikan rancangan masalah yang lebih menarik dan menantang, meningkatkan nilai relevansinya pada saat praktik, meningkatkan rasa keingintahuan terhadap permasalahan yang diberikan dan bertekad untuk menyelesaikannya. Oleh karena itu pembelajaran yang selama ini dianggap pasif dapat berubah menjadi aktif. Sasaran mata kuliah dapat terliput dengan baik dan efisien oleh para mahasiswa. Proses pembelajaran berbasis problem ini akan memberikan waktu yang cukup panjang untuk berdiskusi dan kita harus mengurangi penjelasan dengan metode ceramah untuk merangkup seluruh materi pembelajaran (Puspitasari, 2016).

\section{SIMPULAN}

Setelah melakukan analisis melalui pembahasan di atas, maka penulis dapat 
menyimpulkan adanya pengaruh yang signifikan model pembelajaran TPS terhadap kemampuan crtitical thinking mahasiswa pada mata kuliah Demokrasi Pancasila di Universitas Jambi. Secara umum model pembelajaran Think Pair Share (TPS) lebih baik dibandingkan dengan model pembelajaran konvensional. Dengan demikian, model pembelajaran ini dapat digunakan sebagai salah satu solusi bagi guru/dosen dalam meningkatkan kemampuan berpikir kritis mahasiswa pada mata kuliah Demokrasi Pancasila.

\section{REFERENSI}

Arianti, P. (2011). Pengaruh Penerapan Pembelajaran kooperatif Think Pair and Share (TPS) Terhadap Hasil Belajar Siswa SMA Negeri 8 Surakarta. Jurnal Pendidikan Biologi. Universitas Sebelas Maret, Surakarta.

Balkcom, Stephan. (1992). Cooperative Learning. New Yersey: US Departement of Education.

Buchari. (2009). Manajemen Pemasaran dan Pemasaran Jasa. Cetakan kedelapan,Bandung: Alfabeta.

Cahyono, B. (2016). Korelasi Pemecahan Masalah dan Indikator Berfikir Kritis. Phenomenon: Jurnal Pendidikan MIPA. https://doi.org/10.21580/phen.2015.5.1.87

Fisher, A. (2008). Berfikir Kritis Sebuah Pengantar. Jakarta: Erlangga.

Kemendikbud, T. S. (2003). UU No. 20 Tahun 2003 Tentang Sistem Pendidikan Nasional. Lie, A. (2005). Cooperatif Learning. Jakarta: Gramedia Widiasarana Indonesia.

Moore, Kenneth D. (2005). Effective Instructional Strategies: From Theory to Practice (Third Edit). London: Sage Publication.

Nasution, Adnan Buyung. 2010. Demokrasi Konstitusional. Jakarta: Kompas.

Ndae, Maria Apolonia \& D. A. Widyaningrum (2020). Pengaruh Model Pembelajaran Recripocal Teaching Pair Share dengan Media Gambar Terhadap Kemampuan Berpikir Kritis Siswa SMA. Quagga: Jurnal Pendidikan dan Biologi, 12(1).

Puspitasari, E. (2016). Inovasi Pembelajaran Ilmu Pengetahuan Sosial. Edueksos: Jurnal Pendidikan Sosial \& Ekonomi.

Rosita, I., \& Leonard, L. (2015). Meningkatkan Kerja Sama Siswa Melalui Pembelajaran Kooperatif Tipe Think Pair Share. Formatif: Jurnal Ilmiah Pendidikan MIPA. https:/ / doi.org/10.30998/formatif.v3i1.108

Siregar, T. (2012). Perbedaan hasil belajar kimia menggunakan pembelajaran Think Pair Share (TPS) dengan tipe Numbered Heads Together di SMA YPPK Teruna Bakti Wamena Jayapura. Jurnal Pendidikan Kimia Program Pasca Sarjana UNIMED, 5(2).

Sugiyono. (2014). Metode Penelitian Pendidikan Pendekatan Kuantitatif, Kualitatif, dan $R \mathcal{E D}$. Bandung: Afabeta.

Trianto. (2007). Model-model Pembelajaran Inovatif Berorientasi Konstruktivistik. Jakarta: Prestasi Pustaka.

- (2011). Mendesain Model Pembelajaran Inovatif-Progresif: Konsep, Landasan, dan Implementasinya pada Kurikulum Tingkat Satuan Pendidikan (KTSP/). Jakarta: Kencana. 
Undang-undang Sitem Pendidikan Nasional (UU. No.20 tahun 2003).Jakrta:sinar grafika

Yunita, H., Meilanie, S. M., \& Fahrurrozi, F. (2019). Meningkatkan Kemampuan Berpikir Kritis melalui Pendekatan Saintifik. Jurnal Obsesi : Jurnal Pendidikan Anak Usia Dini. https:/ / doi.org/10.31004/obsesi.v3i2.228. 